\title{
Desmopathy of the front proximal suspensory ligament in conjunction with a metacarpal cortical fracture in a horse: A multi-modality imaging study
}

\author{
Dagmar Berner', Kerstin Gerlach?', Walter Brehm', Christoph Mülling², Sandra Schöniger ${ }^{3}$ and Antonia Lempe-Troillet ${ }^{7}$ \\ 1 Large Animal Clinic for Surgery, Faculty of Veterinary Medicine, University of Leipzig, Leipzig, Germany \\ 2 Institute of Veterinary Anatomy, Faculty of Veterinary Medicine, University of Leipzig, Leipzig, Germany \\ ${ }^{3}$ Institute of Pathology, Faculty of Veterinary Medicine, University of Leipzig, Leipzig, Germany
}

\begin{abstract}
Summary: A Warmblood gelding with a grade 3/5 intermitted lameness was presented for nuclear scintigraphic examination, which revealed focal increased uptake at the left proximal metacarpal region (Figure 1A). Radiographs of this region showed a radiolucent area surrounded by a thin, sclerotic rim. The horse died for reasons unrelated to the lameness. Following, the left forelimb was disarticulated at the elbow joint to further examine the proximal metacarpal region. Ultrasonography showed an enlargement and loss of fibre pattern of the medial lobe of the proximal suspensory ligament (PSL) as well as a focal irregularity of the proximal palmar metacarpal cortex. On transverse T2-weighted magnetic resonance (MR) images the enlargement of the medial lobe could also be detected. Additionally, extensive loss of connective tissue between the PSL and the third metacarpal bone and thickening of the palmar cortex of the metacarpus at this region were seen on MR images. These pathological abnormalities were also detectable with computed tomographic (CT) examination using the soft tissue window. However, CT also demonstrated the presence of a small radiolucent fracture line in the metacarpus. After summarizing all findings the imaging diagnosis of a unilateral, chronic proximal suspensory ligament desmopathy in conjunction with a cortical third metacarpal lesion of the PSL insertion was made. A pathohistological examination confirmed the described imaging findings at the medial lobe of the PSL. Focal areas of granulation tissue and small areas of ossification were detected. The small fracture line at the palmar cortex of the metacarpus was also confirmed by necropsy. Because of its ability to visualize osseous and soft tissue structures, CT-examinations are considered as useful supplementary tool to be included in ambiguous cases of PSL desmopathy.
\end{abstract}

Keywords: horse / suspensory ligament / cortical fracture / computed tomography / magnetic resonance imaging

Citation: Berner D., Gerlach K., Brehm W., Mülling C., Schöniger S., Lempe-Troillet A. (2015) Desmopathy of the front proximal suspensory ligament in conjunction with a metacarpal cortical fracture in a horse: A multi-modality imaging study. Pferdeheilkunde 31, $352-356$

Correspondence: Dr. Dagmar Berner, Chirurgische Tierklinik, Veterinärmedizinische Fakultät, Universität Leipzig, An den Tierkliniken 21 , 04103 Leipzig, Germany, E-Mail: dagmar.berner@vetmed.uni-leipzig.de

\section{Introduction}

Lesions of the proximal suspensory ligament (PSL) occur in equine athletes of different work disciplines (Dyson 2007). Beside the interpretation of clinical signs, diagnosis is routinely based on diagnostic imaging. When lesions are suspected at the PSL, ultrasonography and MRI are routinely used to show alterations in echogenicity or signal intensity respectively. To draw conclusions from those images to age, character and clinical impact of the lesions a certain experience of the examiner is required. Although studies could already show normal and abnormal appearance of the PSL (Labens et al. 2010, Nagy und Dyson 2012), there is only one report where the imaging diagnosis of a clinical PSL injury was correlated to histology (Crass et al. 1992). Histological examined clinical cases confirm interpretation of MRI and sonographic images and provide information for similar cases. Also, the knowledge on how these lesions appear on other imaging modalities can be useful in ambiguous cases, when a PSL injury is clinically not suspected or in horses with multiple injuries.

\section{Case details}

History and Clinical findings

A 16 -year-old, $552 \mathrm{~kg}$, Hanoverian gelding used for dressage was presented to the clinic for a nuclear scintigraphic exami- nation of the forelimbs and neck due to an intermittent, low to mid grade lameness at the left front limb for the last 6 months. A previous lameness examination two months before admission revealed a grade 3/5 lameness (American Association of Equine Practitioners lameness scale) of the left forelimb with a positive flexion test. There was no response to palmar digital nerve blocks and to palmar nerve blocks at the base of the proximal sesamoid bones but a $50 \%$ response to the low 4-point nerve block. Due to the fact, that the horse was not amenable for further diagnostic analgesia and the radiographs of the distal limb taken at this point of time, showed no abnormalities, the horse was sent back home and nuclear scintigraphy was recommended.

\section{Imaging}

Nuclear scintigraphy

Nuclear scintigraphic examinationa was performed following intravenous injection of $5.7 \mathrm{GBq}$ of technetium- $99 \mathrm{~m}$ hydroxymethylen-diphosphonateb ( ${ }^{99 \mathrm{~m} T c-H D P)}$ after 15 minutes (pool phase) and 2 hours (bone phase). Lateral images showed focal increased radiopharmaceutical uptake (IRU) at the left proximal metacarpal region only at the pool phase, whereas in the bone phase a strong focal IRU at the proximal region 
of the left third metacarpus was visible on dorsal images (Figure 1A).

Radiography

Based on these scintigraphic findings dorsopalmar and lateromedial radiographsc, $d$ of the left forelimb were taken. A $9 \times 7 \mathrm{~mm}$ radiolucent area surrounded by a thin, sclerotic rim was found at the metacarpal region with increased IRU (Figure 1B).

\section{Ultrasonography}

A day after those examinations, the horse died for reasons not related to the lameness. The left forelimb was disarticulated at the elbow joint. Subsequently, an ultrasonographic examinatione of the palmar carpal and metacarpal region was per-
A

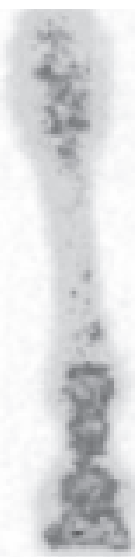

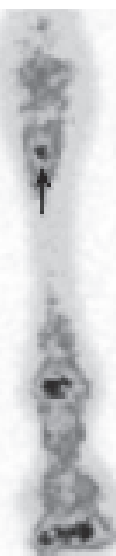

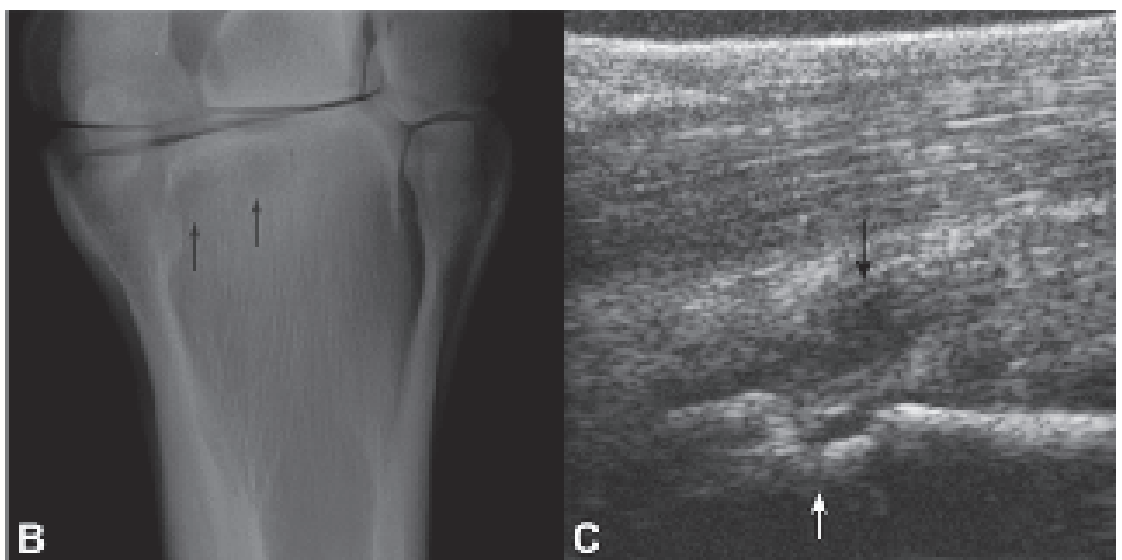

Fig. 1 Dorsal bone phase scintigraphic image of both fore limbs (A). Left is right. There is intense, focally increased radiopharmaceutical uptake at the proximal aspect of the left third metacarpal bone (arrow). Dorsopalmar radiographic image of the left proximal metacarpal region (B). Medial is to left. There is a radiolucent, poorly demarcated area surrounded by a sclerotic rim at the correspondent metacarpal region (arrows). Longitudinal ultrasonographic image obtained $2 \mathrm{~cm}$ distal to the carpometacarpal joint of the left forelimb (C). Distal is to the left. There is a loss of longitudinal fibre pattern as well as a hypo- and anechoic pattern in the medial lobe of the PSL (black arrow). The palmar contour of the proximal metacarpus is irregular (white arrow).

Dorsale szinitigrafische Aufnahme von beiden Vordergliedmaßen (A). Links ist rechts. Im proximalen Bereich des linken Metakarpus 3 ist eine mittelgradige, fokale erhöhte Anreicherung zu sehen (Pfeil). Dorsopalmare röntgenologische Aufnahme des proximalen Metakarpus 3 (B). Medial ist links. In der korrespondierenden Region des linken Metakarpus ist ein schlecht abgegrenzter Aufhellungsbereich mit einem sklerotischen Randsaum zu erkennen (Pfeile). Longituninales Ultraschallbild $2 \mathrm{~cm}$ distal des Karpometakarpal-Gelenkes des linken Vorderbeins (C). Distal ist links. Man sieht einen Verlust der longitudinalen Faserstruktur sowie eine hypo-bis anechogenes Muster im medialen Anteil des Fesselträgers (schwarzer Pfeil). Die palmare Kontur des proximalen Metakarpus stellt sich irregulär da (weißer Pfeil).

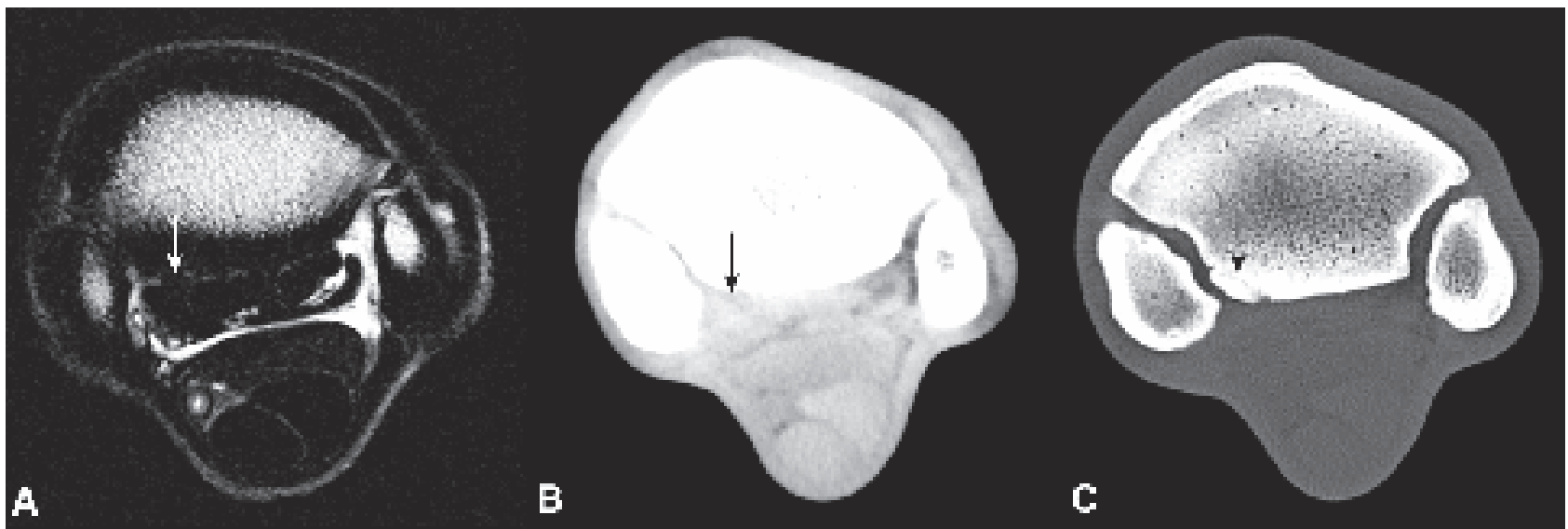

Fig. 2 Transverse T2-weighted MR-image of the left proximal metacarpal region (A). Medial is to the left. The medial lobe of the PSL is irregularly shaped, dorsally enlarged with decreased signal intensity involving the embedded connective bundle. No connective tissue is visible between the cortex of the metacarpus and the PSL (arrow). The medial cortex of the third metacarpal bone is diffusely thickened. Transverse CTimage (soft tissue window) obtained from the same level of the third metacarpus (B). The irregular and enlarged medial lobe of the PSL can be distinguished on this CT image as observed on MR-ones where these abnormalities are nevertheless more obvious and clearly identified (arrow). Transverse CT-image (bone window) of the same region (C). Medial is to the left. The palmar cortex of the third metacarpus is irregular with a small radiolucent fracture line (arrow).

Transversale T2 gewichtete MRT-Aufnahme des proximalen linken Metakarpus (A). Medial ist links. Der mediale Anteil des Fesselträgers stellt sich mit irregulärer Form, dorsal vergrößert und verminderte Signalintensität, die auch das eingebettete Bindegewebe betrifft, dar (Pfeil). Zwischen dem Kortex des Metakarpus 3 sowie dem Fesselträger ist kein Bindegewebe erkennbar. Der mediale Kortex des Metakarpus 3 stellt sich diffus verdickt dar. Transversale CT-Aufnahme (Weichteilfenster) auf ungefähr derselben Höhe des Metakarpus 3 (B). Der irreguläre und vergrößerte mediale Anteil des Fesselträgers ist auf dieser CT-Aufnahme wie schon im MRT, in dem die Veränderungen jedoch deutlicher waren, zu sehen (Pfeil). Transversale CT-Aufnahme (Knochenfenster) derselben Region (C). Medial ist links. Der mediale Kortex des Metakarpus ist irregulär und eine schmale kortikale Aufhellungslinie ist sichtbar (Pfeil). 
formed using a $10 \mathrm{MHz}$ linear transducer with a standoff probe with the leg in extended position. Transversally, enlargement of the medial lobe of the PSL was visible causing an asymmetric appearance of the proximal $2 \mathrm{~cm}$ of the suspensory ligament. Longitudinally, there was a moderate loss of typical parallel aligned fibres. In both sonographic orientations patchy hypo- and anechoic areas within the PSL were
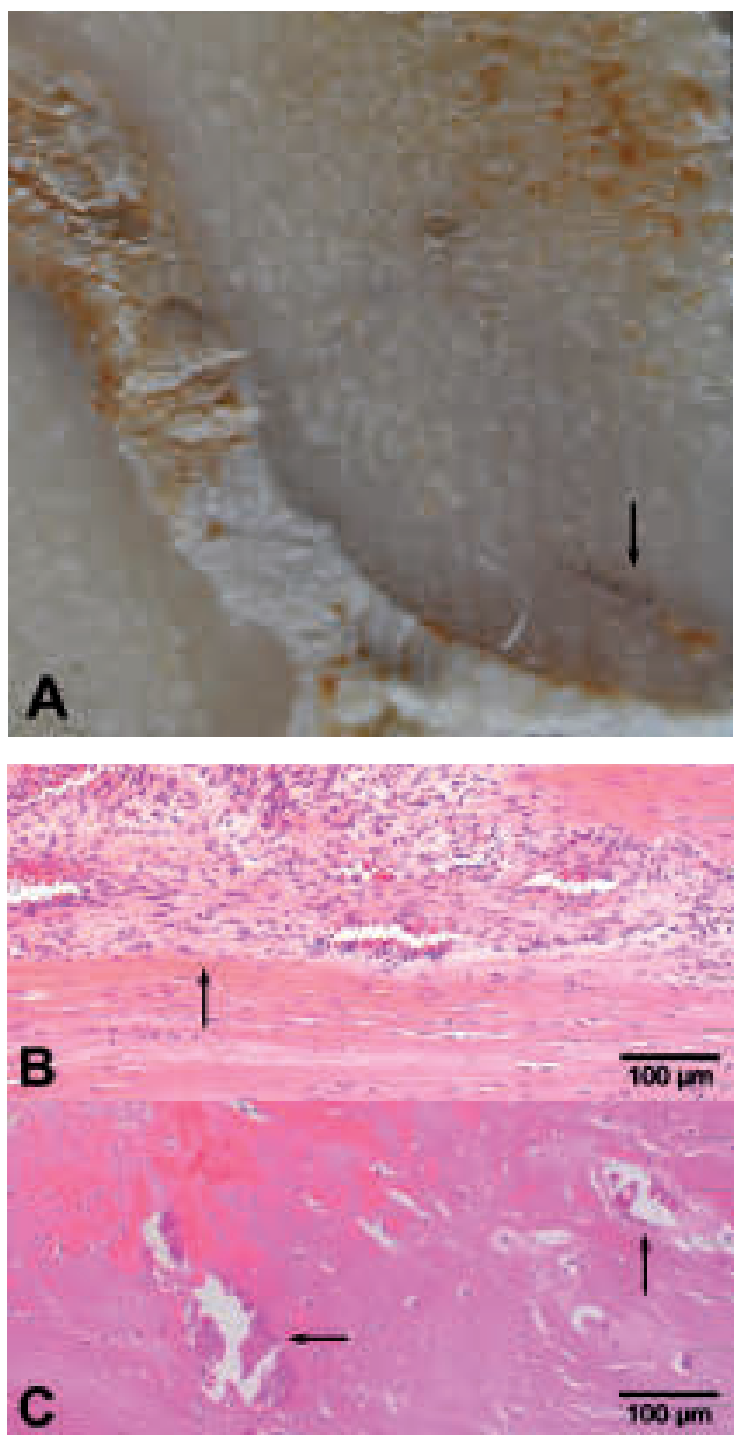

Fig. 3 Photograph of the formalin-fixed specimen of the Mc II \& Mc III (A). Medial is to the left. The cortex of Mc III contains a small focal linear defect consistent with a fracture line (arrow). Micrographs showing the pathohistological findings ( $B$ and $C$ ) (H\&E stained tissue sections). B: The normal architecture of PSL is replaced by the formation of granulation tissue containing thin-walled, dilated vascular structures and minimal infiltration with macrophages, lymphocytes and plasma cells (arrows). C: At the origin of the PSL, small areas of ossification (arrow) are observed. (Scale bar $=100 \mu \mathrm{m}$ ) Fotografie des Formalin fixierten Metakarpus 2 und 3 (A). Medial ist links. Der Kortex des Metakarpus 3 zeigt einen kleinen schmalen fokalen linearen Defekt, der für eine Frakturlinie spricht (Pfeil). Mikroskopische Aufnahmen mit den pathohistologischen Veränderungen (B und C) (Hämatoxilyn-Eosin gefärbtes Gewebe). B: Die normale Architektur des Fesselträgers ist durch Granulationsgewebe mit darin enthaltenen dünnwandigen, dilatierten vaskulären Strukturen und geringer Infiltration von Makrophagen, Lymphozyten und PlasmaZellen ersetzt worden (Pfeile). C: Im Bereich des Ursprungs des Fesselträgers sind kleine Areale von Ossifikation zu erkennen. (Maß$s+a b=100 \mu \mathrm{m})$. also visible. Correspondent to the soft tissue abnormalities, the palmar third metacarpus had a focal, $8 \mathrm{~mm}$ long contour irregularity (Figure 1C).

\section{Magnetic resonance imaging}

MRI of the proximal metacarpal region was performed using a 0.5 Tesla scannerf. The limb was placed parallel to the magnetic field in extended position. T1-weighted spin echo sequences, T2-weighted spin echo sequences and short tau inversion recovery images (STIR) were acquired in transverse, dorsal and sagittal planes. The proximal medial lobe of the PSL showed irregular demarcation, dorsal enlargement and decreased signal intensity of the connective bundle compared to the lateral lobe in all sequences used. The enlargement caused displacement of the adjacent loose connective tissue to the plantar third metacarpus, leading to direct contact of the PSL to the cortical bone. Furthermore, the high signal intensity of the muscle-adipose-tissue-bundle embedded in the medial lobe was not clearly distinguishable from the surrounding hypointense tendon tissue of the PSL. There was also a diffuse and moderate thickening of the medial palmar cortex of the third metacarpal bone (Figure 2A). Because no increase in intensity on T2-weighted images could be demonstrated, the lesion was classified as a chronic lesion.

\section{Computed tomography}

CT was performed using a 16-slice helical scannerg. After transverse and sagittal reconstructions, the soft tissue window revealed pathological findings of the PSL comparable to the MR-findings (Figure 2B). The bone window could clearly demonstrate an irregularity at the medial cortex of the third metacarpus as well as a small radiolucent zone and a small radiodense fragment (Figure $2 \mathrm{C}$ ). After summarizing all findings the imaging diagnosis of a unilateral, chronic proximal suspensory ligament desmopathy in conjunction with a cortical third metacarpal lesion of the PSL insertion was made.

\section{Pathomorphological examination}

At gross examination, the cortex of the third metacarpus displayed a small linear defect consistent with a fracture line (Figure 3A). The medial lobe of the PSL was slightly thicker than the lateral lobe. Within the origin and the medial lobe of the PSL, several small reddish areas were observed. Microscopically, the PSL showed multifocal areas of granulation tissue formation with capillary proliferation, marked hyperaemia and minimal infiltration of lymphocytes, plasma cells and macrophages, some of the latter were haemosiderin-laden (Figure 3B). Multifocal small areas of ossification were observed at the PSL origin (Figure $3 \mathrm{C}$ ).

\section{Discussion}

Given the lack of unambiguous clinical signs and the chronicity of the lameness and because the temperament of the equine patient prohibited further lameness examination, nuclear scintigraphy was regarded essential to localize a pos- 
sible pathologically increased blood perfusion. The focal IRU at the proximal metacarpal region was consistent with a cortical metacarpus fracture. However, similar IRU has been described for longitudinal cortical fractures a condition unrelated to desmitis of the PSL (Dyson et al. 2007, Morgan et al. 2012). Additionally, a low correlation between the presence and intensity of IRU in association with proximal suspensory desmitis in the forelimb is also described without osseous involvement (Dyson et al. 2007). Dorsopalmar radiographs for distinction of the underlying bone condition revealed a sclerotic demarcated radiolucent area, typical for bone remodeling at the attachment of the suspensory ligament (Werpy et al. 2012). Although the radiographic findings provided a suggestive diagnosis, a clear differentiation between a reactive bone sclerosis and a cortical fracture remained impossible. Irregularity of the metacarpal cortex seen on ultrasound was a further indication of an osseous involvement in the disease but not explicit for a fracture (Bertoni et al. 2012, Werpy et al. 2012). Care has to be taken not to change palmar cortex irregularities with the carpometacarpal joint gap. Furthermore, the lesion-related loss of echogenicity has to be assigned correctly as being either a hematoma, edema or granulation tissue or whether these areas represent the physiological embedded muscle-fat-bundles (Nagy und Dyson 2012, Werpy et al. 2012, Werpy et al. 2013). Doppler ultrasonography may distinguish between different stages of highly vascularized granulation tissue in non-cadaver limbs (Kristoffersen et al. 2005). MRI allowed visualization of a unilateral involvement of the muscle-fat-bundle in the morphological destruction of the PSL, the thickening of the dorsal fibrous part of the medial lobe and the thickening of the medial and palmar cortex of the third metacarpal bone. Surprisingly, the fracture line did not occur despite the scintigraphic, radiographic and sonographic findings. It is assumed that an inappropriately chosen MR slice thickness of $3 \mathrm{~mm}$ or the non-existence of bone edema of a chronic, non-reactive sclerosis are possible reasons. Exclusively CT-images were able to precisely demonstrate the osseous lesions by also providing information regarding the PDL injury. Thus, this modality could confirm the possible diagnosis of a cortical fracture by using the soft tissue and bone window reconstruction for interpretation. Although no statement is possible regarding the character of the soft tissue lesion, the findings obtained from the soft tissue window were remarkable correlating with those revealed from MRI. In literature, only a single report exist about CT for PSL in the hind limbs or the bone window setting were used to diagnose an underlying osseous lesion (Launois et al. 2009). In chronic, therapy-resistant clinical cases valuable information can be obtained. The CT-finding of an additional cortical fracture may influence further treatment options and prognosis.

Injuries are commonly defined as desmitis of the PSL regardless the stage of the lesion. In the present case, however, the term desmopathy was considered as the most appropriate diagnosis. Because the histopathological findings showed a chronic PSL alteration and because of the chronic character of the lesion, it cannot be determined whether the initiating cause was a traumatic injury, an acute inflammatory reaction or a degenerative lesion.

However, one limitation of this study is the lack of the regional anesthesia of the PSL that could not be performed due to the temperament of the horse. Therefore, we were only able to assume that lameness in the current case was caused by the abnormalities found in the PSL.

In conclusion, this report could show the value of all currently applicable diagnostic imaging modalities in horses in a case of chronic PSL desmopathy. The underlying condition of a cortical fracture has to be considered. A CT-examination should be included in ambiguous or therapy-resistant cases of PSL lesions by using both, the soft tissue window and bone window for interpretation.

\section{Manufacturer's addresses}

a Medical Imaging Electronics, Seth, Germany

b Mallinckrodt Medical BV, Petten, Netherlands

c Siemens Healthcare, Erlangen, Germany

d Fuji Photo Film GmbH, Düsseldorf, Germany

e GE Healthcare Technologies, Solingen, Germany

f Philips Medical Systems, Hamburg, Germany

\section{References}

Bertoni L., Forresu D., Coudry V., Audigie F., Denoix J. M. (2012) Exostoses on the palmar or plantar aspect of the diaphysis of the third metacarpal or metatarsal bone in horses: 16 cases (20012010). J. Am. Vet. Med. Assoc. 240, 740-747

Crass J. R., Genovese R. L., Render J. A., Bellow E. M. (1992) Magnetic resonance, ultrasound and histopathologic correlation of acute and healing equine tendon injuries. Vet. Radiol. Ultrasound. 33, 206-216

Dyson S. J. (2007) Diagnosis and Management of common suspensory lesions in the forelimbs and hindlimbs of sport horses. Clin Tech Equine Pract. 6,179-188

Dyson S. J, Weekes J. S., Murray R. C. (2007) Scintigraphic evaluation of the proximal metacarpal and metatarsal regions of horses with proximal suspensory desmitis. Vet. Radiol. Ultrasound 48, 78-85

Kristoffersen M., Ohberg L., Johnston C. (2005) Neovascularisation in chronic tendon injuries detected with colour Doppler ultrasound in horse and man: implications for research and treatment. Knee Surg. Sports Traumatol. Arthrosc. 13, 505-508

Labens R., Schramme M. C., Robertson I. D., Thrall D. E., Redding W. R. (2010) Clinical, magnetic resonance, and sonographic imaging findings in horses with proximal plantar metatarsal pain. Vet. Radiol. Ultrasound 51, 11-18

Launois M. T., Vandeweerd J. M., Perrin R. A, Brogniez L., Desbrosse F. G., Clegg P. D. (2009) Use of computed tomography to diagnose new bone formation associated with desmitis of the proximal aspect of the suspensory ligament in third metacarpal or third metatarsal bones of three horses. J. Am. Vet. Med. Assoc. 234., 514-518

Morgan R., Dyson S. (2012) Incomplete longitudinal fractures and fatigue injury of the proximopalmar medial aspect of the third metacarpal bone in 55 horses. Equine Vet. J. 44, 64-70

Nagy A., Dyson S. (2012) Magnetic resonance imaging findings in the carpus and proximal metacarpal region of 50 lame horses. Equine Vet. J. 44, 163-168

Werpy N. M., Denoix J. M. (2012) Imaging of the equine proximal suspensory ligament. Vet. Clin. North Am. Equine Pract. 28, 507 525

Werpy N. M., Denoix J. M., Mclllwraith C. W., Frisbie D. D. (2013). Comparison between standard ultrasonography, angle contrast ultrasonography, and magnetic resonance imaging characteristics of the normal equine proximal suspensory ligament. Vet. Radiol. Ultrasound 54, 536-547 


\section{Erweiterte Zusammenfassung}

\section{Desmopathie des Fesselträgers der Vordergliedmaße in Verbindung mit einer kortikalen Fraktur bei einem Pferd: Eine multimodale bildgebende Studie}

Ein 16 jähriger Warmblut Wallach wurde aufgrund einer mittelgradigen Lahmheit der rechten Vordergliedmaße zur szintigrafischen Untersuchung überwiesen. Dabei konnte eine vermehrte Anreicherung im proximalen Metakarpus festgestellt werden (Abbildung 1A). Röntgenologisch zeigte sich in diesem Bereich ein Aufhellungsareal mit dünnem, sklerotischen Randsaum (Abbildung 1B). Am darauffolgenden Tag starb das Tier aus studienunabhängigen Gründen. Das Vorderbein wurde im Ellbogengelenk exartikuliert. In der nachfolgenden ultrasonographischen Untersuchung wurden eine Auflockerung der Faserstruktur des medialen Anteils des Fesselträgerursprungs sowie eine irreguläre Knochenkontur des palmaren Kortex des Metakarpus in diesem Bereich dargestellt (Abbildung 1C). In der anschließenden magnetresonanztomographischen Untersuchung zeigte sich der Fesselträgerursprung vergrößert mit fokal verminderter Signalintensität am medialen Muskelfaserbündelstrang. Außerdem konnte das typische Muskel-Fett-Bündel innerhalb des Fesselträ- gers nicht klar abgegrenzt werden (Abbildung 2A). Diese, das Weichteilgewebe betreffenden Befunde konnten ebenfalls mit Hilfe der computertomographischen (CT) Untersuchung im Weichteilfenster erhoben werden (Abbildung 2B). Zusätzlich war die CT Untersuchung das einzige Verfahren, welches eindeutig eine kortikale Fraktur des Metakarpus in diesem Bereich darstellen konnte (Abbildung 2C). Daraus folgend wurde eine Desmopathie des Fesselträgers einer Vordergliedmaße in Zusammenhang mit einer kortikalen Fraktur als Ursache für eine chronische Lahmheit vermutet. Pathohistologisch konnten sowohl die Veränderungen im Fesselträgerursprung als auch im proximalen Metakarpus bestätigt werden. Fokal befanden sich Einlagerungen von Granulations- und ossärem Gewebe im medialen Anteil des Fesselträgerursprungs. Die Kortikalfraktur im proximalen Metakarpus konnte ebenfalls bestätigt werden (Abbildung 3). Zur Darstellung dieser komplexen Fesselträgererkrankung in Verbindung mit einer Kortikalfraktur hat sich die CT Untersuchung in dem hier beschriebenen Fall als diagnostisch besonders hilfreich erwiesen. Schlussfolgernd, kann in Fällen mit vieldeutigen Befunden im proximalen Metakarpusabschnitt die CT Untersuchung trotz des größeren klinischen Aufwandes zur Beurteilung von sowohl Weichteil- als auch Knochenveränderungen empfohlen werden.

Schlüsselwörter: Pferd / Fesselträger / kortikale Fraktur / Computertomographie / Magnetresonanztomographie /Szintigraphie / bildgebende Diagnostik 